\title{
Rice Field Sale at the Village of Kuniran, District of Sine, Regency of Ngawi In Islam Perspectives
}

\author{
Murni $^{1}$, Indah Purbasari ${ }^{2}$, Aprilia Dyah Suyanti ${ }^{3}$, Azizah $^{4}$ \\ \{murni@trunojoyo.ac.id ${ }^{1}$, indah.purbasari@trunojoyo.ac.id², apriliadyahsuyanti97@gmail.com³ \\ azizah@trunojoyo.ac.id $\left.{ }^{4}\right\}$ \\ Universitas Trunojoyo Madura, Indonesia ${ }^{1}$, Universitas Trunojoyo Madura, Indonesia ${ }^{2}$, Universitas \\ Trunojoyo Madura, Indonesia ${ }^{3}$, Universitas Trunojoyo Madura, Indonesia ${ }^{4}$
}

\begin{abstract}
Rice field sales on a yearly land tenure conducted by the Kuniran villagers over years are considered legally flawed. Despite the rice field purchase, ownerships are of the same landlords prior to the transactions. Those "unique" transactions inevitably raise questions and trigger legal issues within society as to whether such transactions have met the legal principles revealed in Islam and reasons for maintaining the respective traditions in society and whether such practices are justifiable in Islam. The method of empirical legal research and qualitative approach are used. Furthermore, the result demonstrated that the annual rice sales transactions are illegal under Islam as the sale involves a negative element in fiqh muamalah (a branch of Islamic jurisprudence involving commercial and economic activities) defined as gharar (uncertainty) since there is no deal concerning the ownership tenure settled between the parties involved in the transaction. Therefore, landlords could easily claim the rice fields previously purchased without the buyer's consent at any time. Nonetheless, such land acquisitions make a little difference on the land ownership titles. In other words, the rice fields remain the landlords' property despite the transaction. The business activity has been practiced by the Kuniran villagers out of tradition and economic factor.
\end{abstract}

Keywords: Aqd", rice field annual sale and "urf aqidah

\section{Introduction}

The Kuniran society commonly sell rice fields of which sale contracts last annually to make a living. The rice field owners or landlords usually sell their land to other parties within a certain period and a contract mutually agreed between the land owner and buyer for their benefits. For example, in this transaction, a landlord would sell one acre of rice field with four year tenure for IDR 25,000,000,00 ( twenty five million) to the buyer. In this regard, valid prices are not the market price. Rather, the landlord sets the price on his own estimation and the sale contract should be valid within a particular land tenure. However, the sale contract merely includes the land tenure without stating the precise time of the land handover to its owner. Consequently, the landlord could claim for his land on short notice and without the buyer's advance knowledge. Undoubtedly, these defective business activities have raised issues in Islamic law due to the absence of accepted aqd (agreement) in the transactions and it is seen as gharar (uncertain). Deriving from the background of study, this study aims to conduct an indepth analysis in Islamic perspectives related to the agreement (aqd) made upon the sale of annual-tenure rice fields as to whether such business activity has met the standards and 
requirements determined in Islam and whether the reasons the Kuniran society practice such transactions are justified by the Islamic laws.

\section{Research Methodology}

The study employs the empirical legal research in which collected data is described to oversee how laws are implemented in society and to enhance the society's knowledge on legal issues. Additionally, a qualitative approach is used in this study. In this context, the quality approach is opted to learn about phenomenon on the researched object and elaborate the data needed in the study to produce descriptive data.[1] While the Kuniran society in Sine district, the regency of Ngawi is chosen due to their ongoing business activity in the sale of annualtenure rice fields.

\section{Discussion and Implication}

The village of Kuniran is located in Sine District, approximately 2 kilometers to the north of Sine District. Its area extends to 370,591 acres with a population of 4.196 comprises of 1,070 households. The weather in Kuniran is typically humid as those of other tropical regions that consists of two seasons: the dry and wet seasons. As such, these seasons affect the Kuniran village's planting system.

\subsection{Analysis on the sale of rice fields on a yearly land tenure basis in the Kuniran village,} Sine District in the Regency of Ngawi in Islam legal perspectives.

1. The Sale of Annual-tenure Rice Fields

On daily basis the Kuniran society work on farms to make a living. They generally cultivate their own rice fields or work on acquired rice fields by way of the common system for purchasing annual-tenure rice fields in their village. Historically, such transactions emerged since most villagers owned no rice fields to cultivate. Thus, the sale of annual-tenure rice fields by which the rice field owners were involved, turned out to significantly help the buyers in farming. In practice, land tenures are not restricted to specific time limits as deals were made on the free wills of both parties: the landlord and the buyer.

Once an aqd (agreement) is reached, the buyer is allowed to simultaneously cultivate the rice fields. In the case when the acquired land was fully planted with rice and the harvest time was eminent, the landlord would be entirely entitled to harvest the crops once the tenure expired without prior permission of the buyer.

Within a year of tenure there are three periods of rice plantings: the first planting season or so called the first planting in the wet (rending) season, the second planting occurs in the mid (gaduan) season and the final planting commences in the dry (Javanese language: tigo) season. During the dry season, the lands are planted with produce, chili pepper, vegetables and so forth. When the three seasons have passed by the Kuniran society consider that the land tenure has completely reached a year tenure. 
2. The Price Basis

Prices are mainly determined by the landlords as sellers depending on the land fertility level and frequently applied beyond the market price. In other words, the prices are dependent upon the landlords' estimation.

3. Agreement (aqd) of buying and selling transaction

Agreement is one of the required principles to comply with within a buying and selling transaction. The agreement is reached in the sale of annual-tenure rice fields when the landlord states an oath, "I am selling this rice field for a tenure of a year or two". This agreement is made either verbally or in writing. Upon the end of the sale contract, the buyer would hand the land over to the landlord by stating" the tenure has expired"

The standard and requirements to be met in buying and selling transactions according to the proliferate ulema jumhur ulama are:

a. There are people, specifically sellers and buyers, who hold agreements (al-muta'aqidaini

b. There are contracts (shighat or ijab and qabul).

c. There are merchandise to be offered in the buying and selling transaction.

d. There are means of exchanging the product values.

The compilation of Sharia Law of Economy also governs the methods of acquiring things as stipulated in article $1,[2]$ namely by way of:

a. Trade

b. Legacy

c. Endowment

d. Wills

e. Natural addition

f. Buying and selling transaction

g. Luqathah

h. Waqf

i. Other mechanisms provided that they are accepted in sharia

According to syafi'iyah doctrine, buying and selling transactions are agreements made upon trading things to transfer the item ownership or benefits eternally. In addition, the perception over buying and selling transactions stated in the Fatwa of Sharia Council of MUI No. 110/DSN-MUI/IX/2017 is agreements achieved between a seller (al-ba'i) and a buyer (almusytari) that subsequently results in the transfer of ownership of traded items (mabi'/mustman) and the item price (tsaman). The definition of ba'i described in Article 20 of the compilation of Sharia Law of Economy is buying and selling transactions between items or trading items with money. The Fatwa of Sharia Council of MUI No. 112/DSN-MUI/IX/2017 asserts that Aqd Ijarah is a contract made for renting property between mu'jir and musta'jir or a contract made between musta'jir and ajir to trade manfa'ah and ujrah, for the benefits of both parties either in terms of items or services.[3] In short, ijarah jarah is a contract by which items or services are rented in favor of both parties. The Hanafiyah ulema claim that ijarah standard performance is ijab and qabu,l among other thing, by stating al-ijarah, al-isti'jar, al-iktira and al-ikra words of oath. While other ulema state that ijarah ijarah standard performance consist of four elements:
a. 'Aqid (people who reach an agreement)
b. Sighat (ijab and qabul)
c. Ujrah (rewards as in tips)
d. Benefits

Whereas the ijarah should be considered legal in Islamic law provided that: 
1. There is an agreement between parties.

2. There are definite or specified contracts, benefits and objects involved in the agreement.

3. There are ma'qud alaih benefits that in general meet the purpose of making the agreement (aqad ijarah).

Based on the elaboration above, buying and selling transactions are agreements made for voluntarily trading products or valuable items among parties involved . Such agreement should last for eternity; one party accept the item/product, whereas the other accepts it according to the justified syara'(rules) and agreement. As stated in the first rule (rukun) on people (the buyer and the seller) who reach an agreement within aqd ijarah, the parties involved are mu'jir and his musta'jirnya, baligh (physically mature), sensible people on their free wills and capable of managing his wealth as well as understanding issues related to the transaction. While the second rule known as shighat which means to make a contract (ijab and qabul) as exercised in the sale of annual-tenure rice fields by the Kuniran society wherein two contracts are made: a contract of buying and selling and aqd ijarah, to which the seller makes an oath (ijab) upon the transaction by saying "I am selling my rice field to you" and qabul (expression of approval) is uttered by the seller to express the tenure which is valid on yearly basis. The object used in this transaction is considered lawful as there is no specific duration applied regarding the land occupation. Therefore, no rules nor requirements are fulfilled in this transaction due to numerous uncertain (gharar) elements: first, the contract is less specific as to whether it is a buying and selling contract or aqd ijarah (lease) is applied in the transaction. Hence, the transaction is considered as unlawful according to the Islamic law due to misfit in its practice. The rice field is meant to be sold along with the transfer of land ownership to the benefits of the buyer. The absence of land ownership given to the buyer fails to justify the transaction as a buying and selling activity in Islamic law. Instead, it is considered as merely a lease (ijarah).

Furthermore, through the analysis on the sale of rice fields on annual basis, the Kuniran society have met the standards and requirements related to the way how the trade was performed. There were objects traded by both parties involved in the sale of rice fields despite the absence of land ownership or rights given to the buyer as it is compulsory and the seller is obliged to hand the ownership to the buyer. Additionally, rules and requirements in buying and selling transactions, according to Syafi'I doctrine (mazhab) are described as follows:[4]

1. Both parties face toward each other. The buyer and seller both show their oaths as their approval to each other. The oaths are correctly stated to the right person to whom he has the deal with. For example, the seller should say "I am selling this to you!" and he shall not state, "I am selling this to Ahmad," to the buyer whose name is not Ahmad.

2. The oaths are meant to be stated to the entire limb of the buyer. Thus, it is unlawful to say "I am selling this thing to your head or hand".

3. Qabul is stated toward the party with whom he (the one who utters ijab) has the contract unless he is represented by the other party.

4. Both parties shall mention the item and its price traded

5. Oaths are stated upon free wills.

6. Ijab and qobul should be perfectly stated. Thus, mentally ill parties shall never utter qobul Otherwise, the contract is called off.

7. Ijab qabul is held at the same time and venue. No prolonged response should be given after ijab is said by the first party as this represents disapproval of the second party.

8. Ijab qobul should be stated precisely. For example, "I am selling this for five thousand rupiahs". However, momentarily the ijab is changed by saying" I am selling this for ten thousand rupiahs" in spite of the same product mentioned and the buyer has yet reached agreement on it. 
9. The transactions performed are in accordance with ijab and qabul as long as

10. The transactions are related to particular matters.

11. The transactions are not related to matters beyond the contract.

12. The transactions are not related to any particular time period that triggers the removal of ownership of the objects traded in buying and selling transactions

As stated in Article 91 KHES "Lawful and binding transactions of buying and selling shall result in the transfer of ownership of the traded objects". The Article 92 number (1) of KHES states that: "Canceled transactions of buying and selling do not necessarily result in the ownership transfer".[2] Furthermore, regarding the Article 91 and Article 92 of KHES, it is revealed that the Kuniran society have failed to meet the standards of lawful transaction and consequently the contract is called off due to the statement wherein land tenure should be applied in the transaction without the transfer of land ownership from the seller to the respective buyer.

\subsection{The underlying reasons for selling rice fields on a yearly land tenure}

Such practices of selling rice fields on a yearly land tenure, as mentioned in earlier discussions, serve as a tradition preserved over generations in the Kuniran society. For instance, Mr. Sadiman, the rice field owner who sold his land to Mr. Nano. He said that his ancestors have been dealing with such transaction for over lengthy period of time and similar practice has been conducted by others in the Kuniran society.The Chief of Kuniran village, Djoko Sukendro, also commented that the sale of rice fields on yearly land tenure has been in the tradition. There should be no other possible methods capable of replacing such transaction into a lease contracts. He assumed that the alternative lease contract would only be operable on office building or house rents. Hence, the underlying reason why such rice fields sale remain in practice to the present time is that it has turned into their customs their ancestors have inherited over generations.

\subsection{Qaidah 'Urf implementation within the sale of rice fields on yearly basis}

The sale of rice fields on yearly basis practiced by the Kuniran society has been taken as a legacy and it functions as the custom law provided no controversy emerged in the Islamic laws. A fiqh qaidah can likely serve as a custom law and a few fiqh ulema claim that 'urf can refer to customs despite no differences found between urf and customs. Society embrace customs as habits they perform on daily basis. In other words, customs are common and practiced by society. Assumingly, customs are unwritten rules of which sanctions are imposed to those who violate the customs [5]. While "Urf" is widely known and practiced by the society in terms of actions or expressions or behaviors they avoid. These are also called as "al-adah"[6].

The "urf has been accepted as a legal source by the Islamic law. It is divided into several parts. According to its legal form 'urf is divided into: Al-urf qauliyah, namely common habits practiced in actions and speeches. For example, Waladun literally means a child referred to a boy or girl, although in practice, it is merely regarded as a boy. Al-urf al-fi'ly, namely common habits in actions, among other things, in buying and selling activities wherein no utterance (ijab qabul) is produced to pronounce the transaction. Whereas the Islamic laws suggest that ijab qabul is compulsory and serve as the rule of conducting buying and selling transactions. Gradually such habits are permitted in the Islamic laws since there are no negative implication resulted with the absence of 'ijab qabul in the transaction. However, the transaction of rice field sale practiced by the Kuniran society unlikely function as 'urf' due to its uncertain (gharar) characteristics found in its agreement. 


\section{Conclusion}

The agreement, made by the Kuniran society in Sine District, the regency of Ngawi, on rice field sale on yearly basis land tenure initially failed to meet the Islamic law standard as it is considered unlawful due to gharar (uncertain) land tenure stated in sighat upon the rice field handling. There are two factors why such tradition has been maintained over generations: cultural habit and economic necessities. Such tradition fails to function as qaidah 'urf due to lacking in decency within the Islamic laws

\section{Suggestion}

The sale of rice fields on annual basis should not be practiced by the Kuniran society. Instead, a lease contract (aqd ijarah) should be recommended to replace the unlawful transaction to support their life as it is least debatable within the Islamic laws. Furthermore, the Kuniran society should shift their mindset as not to sell rice fields on annual basis as the only way to fulfill their needs.

\section{References}

[1] M. F. ND and A. Yulianto, Dualisme Penelitian Hukum Normatif \& Empiris. Yogyakarta: Pustaka Pelajar, p. 193, 2010.

[2] Mahkamah Agung, Kompilasi Hukum Ekonomi Syariah. Jakarta: Mahkamah Agung Republik Indonesia, 2008.

[3] Dewan Syariah Nasioal Majelis Ulama Indonesia, Fatwa Dewan Syariah Nasioal Majelis Ulama Indonesia No. 110/DSN-MUI/IX/2017 tentang Ijarah. Jakarta: Dewan Syariah Nasioal Majelis Ulama Indonesia, 2017.

[4] E. Hidayat, Fiqih Jual Beli. Bandung: Remaja Rosdakarya, p. 9, 2015.

[5] A. Sanusi and Sohari, Ushul Fiqh. Jakarta: Raja Grafindo Pustaka, p. 84, 2015.

[6] R. Syafei, Fiqh Muamalah. Bandung: Pustaka Setia, p. 104, 2001. 